\title{
PERAN AGEN ASURANSI SYARIAH DALAM MENINGKATKAN PEMAHAMAN MASYARAKAT TENTANG ASURANSI SYARIAH
}

\section{Edi Hariyadi dan Abdi Triyanto ${ }^{1}$}

\author{
I'Afiliasi: Sekolah Tinggi Ekonomi Islam SEBI. Email: ediharyadi303@yahoo.co.id
}

\begin{abstract}
ABSTRAK. Permasalahan yang akan diangkat dalam penelitian ini adalah bagaimana peran seorang agen asuransi dalam meningkatkan pemahaman terhadapa asuransi takaful. Dalam penelitian ini juga berusaha menjawab bagaimana sikap perilaku nasabah terhadap eksistensi asuaransi syariah. Kedua bagaimana kerja keras seorang agen asuransi syariah dalam meningkatkan kesadaran masyarakat. Model penelitian ini adalah penelitian kepustakaan. Hasil daripada penelitian ini, agen memiliki peran dalam mengakses informasi, menjaga image asuransi syariah, memberikan solusi dan konsultasi terhadap nasabah yang prospektif. Dengan begitu, pemahamanan masyarakat akan manfaat takaful akan menjadi lebih baik.
\end{abstract}

Keywords: Agent Asuransi Syariah, Peran Agen asuransi syariah, pemahaman masyarakat

\begin{abstract}
The subject matter to be discussed in this paper is how the role of an Islamic insurance agent in increasing public understanding of Takaful. In addition this paper will try to answer: how people's attitude toward the existence of Islamic insurance; and how should the efforts of an Islamic insurance agent to increase insurance awareness for the community. This paper focuses the discussion of an agent as an intermediary between the Takaful Islamic insurance company with the community. The method used in this paper is to study literature (Library Research), namely by rethinking simultaneously collects some writing and previous research results related to the presence and role of the function of an agent. This results in writing that there are a few roles Takaful agent, such as access to information, guard the good image of Islamic insurance companies, power marketers Islamic insurance products, providing solutions and services to prospective customers as well as provide insight to the public right of Takaful. On the basis of the understanding of Takaful then the public will know and understand the importance of using Takaful.
\end{abstract}

Keywords: Islamic Insurance Agent, Role of Agent, Understanding of society

\section{PENDAHULUAN}

Indonesia sebagai salah satu negara yang penduduknya padat juga mayoritas adalah beragama Islam. Hal tersebut selalu menjadi sorotan para pengamat, khususnya dibidang syariah perihal peluang yang diperoleh Indonesia sangatlah besar sebagai pangsa pasar sektor syariah (Ekonomi-Bisnis, 2014). Sejak berdirinya industri asuransi syariah pertama di Indonesia, yakni Asuransi Takaful Keluarga dan Asuransi Takaful Umum di tahun 1994, saat sampai tahun 2014 jumlah industri asuransi syariah di Indonesia telah 
bertambah menjadi 48 (empat puluh delapan) industri. Pertambahan tersebut merupakan pencapaian yang baik bagi perkembangan asuransi syariah di Indonesia.

Grafik 1. Perkembangan Jumlah Industri Asuransi Syariah di Indonesia

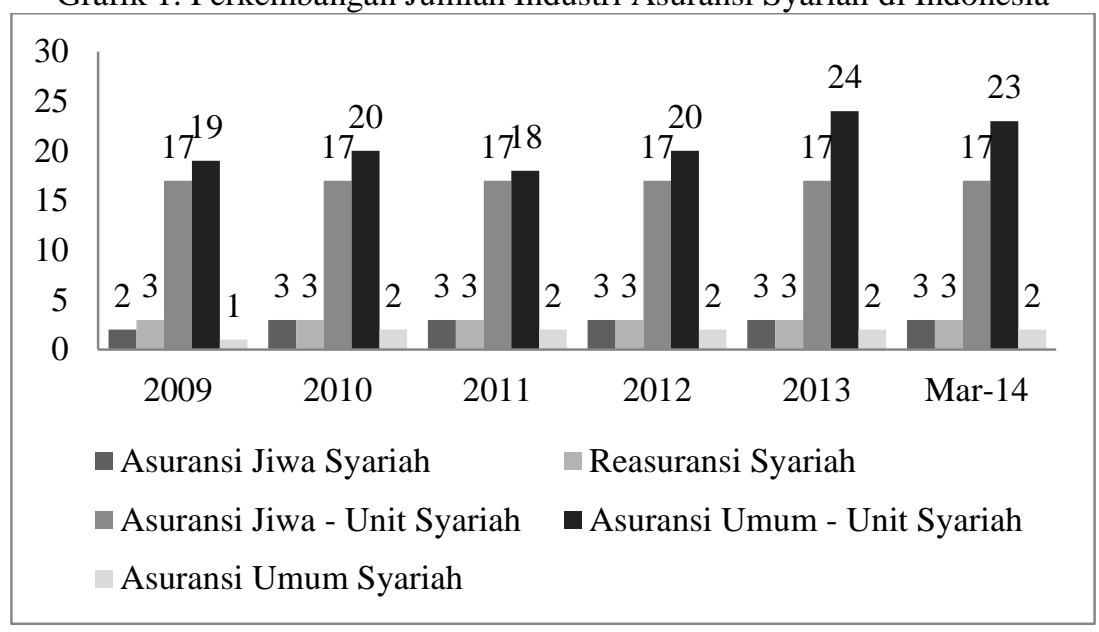

Sumber : Karim Consulting Indonesia 2015 (Outlook Keuangan Syariah)

Data grafik di atas menjelaskan bahwa sejak tahun 2009 sampai tahun 2014, jumlah asuransi jiwa syariah mengalami mengalami pertambahan sebanyak 1 menjadi 20 asuransi jiwa syariah. Sementara masih dalam periode yang sama jumlah asuransi umum pertambahan asuransi umum lebih besar, yaitu 6 perusahaan menjadi 26 perusahaan. Namun pada februari 2014 jumlah perusahaan asuransi umum syariah menurun menjadi 25 perusahaan. Hal tersebut disebabkan oleh di cabutnya izin usaha cabang syariah asuransi Toko Marine oleh Otoritas Jasa Keuangan (OJK).

Akan tetapi pada Triwulan ke IV tahun 2014 jumlah total aset asuransi dan reasuransi syariah masih kecil jika dibandingkan dengan asuransi dan reasuransi konvensional (AASI, 2014). Pada asuransi jiwa syariah, total asetnya (dalam milyar) adalah sebesar Rp. 18,051.63, sedangkan pada asuransi jiwa konvensional asetnya mencapai angka sebesar Rp. 323,150.84, dengan market share asuransi syariah hanya sebesar 5,29\%. Begitupun halnya pada asuransi umum dan reasuransi syariah, total asetnya sebesar Rp. 4,312.72, sedangkan pada asuransi umum dan reasuransi konvensional asetnya sebesar Rp. 117,679.90, dengan market share asuransi syariah hanya sebesar 3,54\%. Dan total semuanya, aset pada asuransi dan reasuransi syariah sebesar Rp. 22,364.35, sedangkan pada asuransi dan reasuransi konvensional sebesar Rp. 440,830.74, dengan market share asuransi syariah hanya sebesar 4,83\%. Dapat disimpulkan bahwa market asuransi syariah masih kecil jika dibandingkan dengan asuransi konvensional.

Tabel 1. Perbandingan total aset Asuransi dan Reasuransi Syariah dengan Konvesional Triwulan IV Tahun 2014 (dalam Milyar)

Keterangan $\quad$ Asuransi dan $\quad$ Asuransi dan Market


Jurnal Ekonomi dan Perbankan Syariah

Vol. 5. No.1, April 2017: 19-37, ISSN (cet): 2355-1755 | ISSN (online): 2579-6437

| 21

\begin{tabular}{lccr}
\hline & $\begin{array}{c}\text { Reasuransi } \\
\text { Syariah }\end{array}$ & $\begin{array}{c}\text { Reasuransi } \\
\text { Konvensional }\end{array}$ & \multicolumn{1}{c}{$\begin{array}{c}\text { Asuransi } \\
\text { Syariah } \\
\text { dengan Total }\end{array}$} \\
\hline $\begin{array}{l}\text { Asuransi Jiwa } \\
\text { Syariah }\end{array}$ & $18,051.63$ & $323,150.84$ & $5,29 \%$ \\
\hline $\begin{array}{l}\text { Asuransi Umum } \\
\text { dan Reasuransi }\end{array}$ & $4,312.72$ & $117,679.90$ & $3,54 \%$ \\
\hline $\begin{array}{l}\text { Jumlah Asuransi } \\
\text { dan Reasuransi }\end{array}$ & $22,364.35$ & $440,830.74$ & $4,83 \%$ \\
\hline
\end{tabular}

Sumber: AASI (2014)

Dari penelitian yang dilakukan oleh Gunistiyo dan Subekti (2001), tingkat kesadaran masyarakat tegal dalam berasuransi mencatat bahwa tingkat kesadaran masyarakat dalam berasuransi masih rendah. Kesadaran masyarakat untuk berasuransi dipengaruhi oleh faktor tingkat pendidikan dan tingkat pendapatan masyarakat. Semakin tinggi tingkat pendidikan dan tingkat pendapatan masyarakat maka semakin tinggi juga kesadaran masyarakat untuk berasuransi (Subekti, 2001, hal. 5).

Mohammad Johari (2010) dalam penelitiannya yang berjudul Respon Masyarakat Muslim kota Mataram terhadap Asuransi Syariah juga mencatat tentang kondisi hubungan masyarakat dengan asuransi syariah. Disebutkan bahwa dukungan akan asuransi syariah, karena seorang muslim maka sangat tinggi. Jadi komposisi masyarakat muslim menjadi faktor yang mempengaruhi dukungan terhadap asuransi syariah. Akan tetapi masyarakat masih ragu untuk menyampaikan informasi dan mengajak bergabung dengan asuransi syariah atau dengan kata lain perluasan penyebaran informasi menjadi terhambat (Johari, 2010, hal. 152).

Dalam perusahaan asuransi, baik umum maupun umum syariah diketahui adanya peran seorang agen yang memiliki pengaruh langsung terhadap perusahaan asuransi yang bersangkutan. Sistem pemasaran yang terdapat dalam perusahaan asuransi dilakukan oleh seorang agen. Seorang agen menjadi pemeran utama dalam meningkatkan pemasaran asuransi. Dalam perkembangannya, pada tahun 2011 terdapat sebanyak 21 unit perusahaan agen asuransi. Pada tahun 2013 dan 2014 jumlah perusahaan agen asuransi bertambah menjadi 25 unit. Keberadaan perusahaan agen asuransi ini diharapkan dapat membantu meningkatkan kualitas daripada agen asuransi.

Pada tanggal 21 Oktober tahun 2015 dalam siaran pers Otoritas Jasa Keuangan (OJK) disebutkan, pihaknya tengah mempersiapkan 10 juta agen asuransi dan 1.000 sahabat keuangan maritim. Kegiatan tersebut dimaksudkan untuk meningkatkan akses masyarakat kepada layanan asuransi, asuransi mikro dan syariah serta memperluas jangkauan layanan keuangan pelaku industri dan kelautan. Ketua Dewan Komisioner OJK Muliaman D Haddad menjelaskan perekrutan 10 juta agen asuransi ini diharapkan dapat terwujud dalam beberapa tahun sehingga akses dan 
transaksi atas produk asuransi, khususnya produk asuransi mikro dan syariah bisa meningkat (OJK, 2015).

Seorang agen takaful, agen asuransi syariah tidak hanya diwajibkan untuk menjual produk asuransi syariah, akan tetapi mereka juga diwajibkan untuk mendidik Masyarakat berkaitan dengan tujuan dan pentingnya produk asuransi syariah (Marhanum Che Mohd Salleha, 2013, hal. 20). Melihat dan menilai betapa beratnya tanggung jawab seorang agen maka pemerintah membuat regulasi yang mengharuskan seorang agen memiliki sertifikasi. Untuk menunjang peraturan tersebut pemerintah telah menargetkan untuk memberikan sertifikasi kepada agen asuransi umum pada tahun 2010 sebanyak 7500 agen untuk seluruh wilayah Indonesia (Saharuddin, 2014, hal. 208-209). Besar harapan pemerintah melalui sertifikasi tersebut akan mampu mendorong setiap agen untuk bekerja secara profesional.

\section{TELAAH PUSTAKA}

\subsection{PENGERTIAN ASURANSI SYARIAH}

Pada Kitab Undang-Undang Hukum Dagang (KUHD) pasal 246 dijelaskan bahwasanya asuransi adalah "suatu perjanjian, dengan mana seorang penanggung mengikatkan diri kepada seorang tertanggung dengan suatu premi untuk memberikan penggantian kepadanya karena suatu kerugian, kerusakan atau kehilangan keuntungan yang diharapkan, yang mungkin akan di deritanya karena suatu peristiwa yang tak tertentu" (Ali, 2008, hal. 1).

Asuransi syariah merupakan suatu cara dalam mengelola risiko yang dimungkinkan datang yang sesuai dengan syariat, saling menolong antar sesama yang melibatkan peserta dan operator (Iqbal, 2005, hal. 2). Jadi dalam pengertian ini ada kelompok yang berperan sangat dalam Asuransi syariah melibatkan Masyarakat umum, peserta asuransi dan operator.

Dewan Syari'ah Nasional pada tahun 2001 telah mengeluarkan fatwa mengenai asuransi syariah. Dalam fatwa DSN No. 21 / DSN-MUI / X / 2001 bagian pertama mengenai Ketentuan Umum angka I disebutkan pengertian asuransi syari'ah (ta'min, takaful, atau tadhamun) adalah usaha saling melindungi dan tolong menolong diantara sejumlah orang/pihak melalui investasi dalam bentuk aset dan atau tabarru' yang memberikan pola pengembalian untuk menghadapi risiko tertentu melalui akad (perikatan) yang sesuai dengan syari'ah.

Asuransi Syariah, pada asuransi yang dikenal dengan nama lainnya adalah asuransi ta'awun ini yang dikejar bukanlah keuntungan namun tujuannya adalah sosial. Yaitu, para peserta atau pelakunya saling bahu membahu dan tolong menolong dalam menghadapi suatu musibah yang kedatangannya tidak bisa dipastikan secara pasti. Pada praktiknya peserta menanggung (menjamin) dirinya sendiri. Adapun peran perusahaan hanya sebagai penengah diantara para peserta asuransi atau nasabah-nasabah yang tertanggung (Al-Bugha, 2009, hal. 83). Hal tersebut yang menjadi pembeda antara asuransi syariah dengan asuransi yang lainnya. 
Jurnal Ekonomi dan Perbankan Syariah

Vol. 5. No.1, April 2017: 19-37, ISSN (cet): 2355-1755 | ISSN (online): 2579-6437

| 23

Dari beberapa pengertian diatas dapat diambil kesimpulan bahwa Asuransi Syariah adalah suatu ikatan perjanjian untuk saling tolong menolong satu sama lain atau saling melindungi atas barang berharga milik orang satu dengan yang lainnya dalam rangka mewujudkan suatu kesejahteraan secara merata tanpa terkecuali yaitu dengan berlandaskan pada Al Quran dan As Sunnah yang diamalkan dalam kehidupan setiap hari.

\subsection{AKAD-AKAD DALAM ASURANSI SYARIAH}

Dalam Fatwa DSN-MUI N0.21/DSN-MUI/X/2001 tentang pedoman umum asuransi syariah juga di tegaskan bahwa yang dimaksud dengan akad tijarah adalah Mudharabah sedangkan yang dimaksud dengan akad tabarru' adalah hibah. Dalam akad tijarah, perusahaan bertindak sebagai mudharib (pengelola) dan peserta bertindak sebagai shahibul maal (pemegang polis). Dengan penegasan mengenai akad dalam asuransi syariah tersebut dapat disimpulkan mengenai penerapan kedua akad tersebut, yaitu akad tijarah akan cenderung cocok untuk asuransi kerugian sedangkan akad tabarru' akan cenderung cocok untuk asuransi jiwa.

Berikut konsep dan implementasi akad mudharabah dan akad tijarah lainnya pada asuransi syariah (Sula, 2004, hal. 329-358):

\subsubsection{Mudharabah}

Wahbah Zuhaili dalam al-Fiqih al-Islam wa 'Adilluhu mengatakan bahwa definisi mudharabah adalah pemilik harta ( rabbul maal) memberikan kepada mudharib 'orang yang bekerja atau pengusaha' suatu harta supaya dia mengelola dalam bisnis dan dibagi antara mereka berdua mengikuti syarat yang mereka buat.

Adapun rukun mudharabah adalah adanya mudharib, ada pemilik dana, ada usaha yang dibagihasilkan, ada nisbah, dan ada ijab qabul. Sementara itu, Syafi'i Antonio mengatakan bahwa rukun mudharabah adalah pemodal (shahibul maal), pengelola (mudharib), modal (maal), nisbah keuntungan, dan sighat (aqd).

Dalam Fatwa Dewan Syariah Nasional No: 51/DSN-MUI/III/2006 tentang Akad Mudharabah Musytarakah pada Asuransi syariah disebutkan bahwa Mudharabah Musytarakah boleh dilakukan oleh perusahaan asuransi, karena merupakan bagian dari hukum Mudharabah. Dalam akad Mudharabah Musytarakah ini, perusahaan asuransi sebagai mudharib menyertakan modal atau dananya dalam investasi bersama peserta. Kemudian, modal atau dana perusahaan asuransi dan dana peserta diinvestasikan secara bersama-sama dalam bentuk portofolio. Mengenai hasil investasi, pembagian bagi hasilnya dapat dilakukan dengan dua alternatif, yaitu:

1. Hasil investasi dibagi antara perusahaan (sebagai mudharib) dan peserta (sebagai shahibul mal) berdasarkan pada nisbah yang disepakati. Bagian hasil investasi sesudah diambil oleh/dipisahkan untuk/disisihkan untuk Perusahaan Asuransi (sebagai mudharib), 
dibagi antara Perusahaan Asuransi (sebagai musytarik) dengan para peserta sesuai dengan porsi modal masing-masing.

2. Hasil investasi dibagi secara proporsional antara dana perusahaan (sebagai musytarik) dan peserta (shahibul mal) berdasarkan porsi modal masing-masing. Bagian hasil investasi sesudah diambil oleh/dipisahkan untuk/ disisihkan untuk Perusahaan Asuransi sebagai mudharib dengan nasabah dana yang sesuai dengan porsi modal masing-masing.

\subsubsection{Wakalah}

Wakalah atau wikalah berarti penyerahan, pendelegasian, atau pemberian mandat. Jadi, wakalah merupakan pelimpahan, pendelegasian wewenang atau kuasa dari pihak pertama kepada pihak kedua untuk melaksanakan sesuatu atas nama pihak pertama dan untuk kepentingan dan tanggung jawab sepenuhnya oleh pihak pertama.

Dalam Fatwa Dewan Syariah Nasional No: 52 /DSN-MUI/III/2006 Tentang Akad Wakalah bil Ujrah Pada Asuransi Syariah dan Reasuransi Syariah disebutkan bahwa Akad Wakalah bil Ujrah boleh dilakukan oleh perusahaan asuransi dengan peserta asuransi. Akad Wakalah bil Ujrah adalah pemberian kuasa dari peserta kepada perusahaan asuransi untuk mengelola dana peserta dengan imbalan pembelian ujrah (fee). Yaitu Perusahaan asuransi bertindak sebagai penerima kuasa dari peserta sebagai pemberi kuasa untuk dapat mengelola dana peserta. Dalam pelaksanaannya, perusahaan asuransi tidak boleh mewakilkan lagi tanpa seizin pemberi kuasa atau peserta. Oleh karena ada ujrah maka perusahaan tidak berhak atas hasil pengelolaan dana, investasi dan juga tidak berkewajiban menanggung resiko atas kerugian dalam mengelola dana peserta, kecuali atas dasar kecerobohan atau wanprestasi.

\subsubsection{Wadi'ah}

Al-Wadi'ah dapat diartikan dengan meninggalkan atau meletakkan, yaitu meletakkan sesuatu pada orang lain untuk dipelihara atau dijaga. Sedangkan, menurut istilah, al-Wadi'ah adalah memberikan kekuasaan kepada orang lain untuk menjaga hartanya/barangnya dengan secara terang-terangan atau isyarat yang semakna dengan itu. Dalam praktik asuransi syariah, Asuransi Mubarakah Syariah (life insurance) menggunakan akad wadi'ah. Dana terkumpul dari nasabah dititipkan kepada perusahaan asuransi (Mubarakah) untuk dikelola seperti halnya akad wadi'ah yang ada di bank syariah, hanya saja dalam asuransi mengandung unsur asuransi dengan nilai pertanggungan sesuai yang diperanjikan. 
Jurnal Ekonomi dan Perbankan Syariah

Vol. 5. No.1, April 2017: 19-37, ISSN (cet): 2355-1755 | ISSN (online): 2579-6437

25

\subsubsection{Musyarakah}

Musyarakah ialah perjanjian (akad) antara dua pihak atau lebih dalam sautu usaha tertentu. Masing-masing pihak memberikan kontribusi dengan kesepakatan kalau terdapat keuntungan dan atau mengalami kerugian masing-masing pihak mendapatkan margin dan menanggung resiko kerugian sesuai dengan kesepakatan di awal akad. Akad musyarakah dilandasi oleh keinginan kedua belah pihak yang ingin bekerja sama dalam sebuah usaha untuk meningkatkan nilai aset yang dimiliki masing-masing pihak secara bersamaan.

Pada hakikatnya bentuk kerja sama dalam asuransi adalah bentuk kerja sama yang dilandasi oleh prinsip al-Musyarakah, dimana ada pihak yang punya dana dan modal, dan ada pihak yang hanya memiliki tenaga dan skill serta profesioanlisme. Karena sejatinya Manusia diciptakan oleh Allah swt dengan kelebihan dan kekurangannya masing-masing. Oleh karena itu, konsep al-Musyarakah menjadi suatu kebutuhan.

\subsection{PRINSIP-PRINSIP ASURANSI SYARIAH}

Beberapa prinsip Asuransi Syariah yang harus dijadikan pedoman dalam mewujudkan kesejahteraan sesama peserta asuransi adalah sebagai berikut (Ali, 2008, hal. 24-28) :

1. Saling bertanggung jawab, tanggung jawab setiap muslim merupakan kewajiban. Tanggung jawab yang dimaksud, dapat muncul dari adanya sikap saling menyayangi, saling mencintai, saling membantu, dan saling meningkatkan kebersamaan sesama muslim.

2. Saling bekerja sama dan saling membantu, kerja sama dimaksud adalah saling menguntungkan atau saling menanggung risiko. Islam mengajarkan betapa pentingnya kerja sama di antara warga masyarakat dalam banyak hal. Misalnya, diungkapkan bahwasanya bilamana seseorang berutang untuk hal yang baik, kemudian tidak mampu untuk melunasinya maka menjadi kewajiban umat islam untuk membantu membayarnya secara bersama-sama.

3. Saling melindungi, yaitu orang yang kuat melindungi yang lemah, orang kaya melindungi orang miskin, pemerintah menjadi pelindung terhadap kesejahteraan dan keamanan rakyatnya.

4. Mewujudkan keselamatan, keselamatan dimaksud bersifat komprehensif sehingga setiap warga masyarakat islam harus memiliki pemikiran untuk saling menolong dan bekerja sama atau memiliki prinsip yang dapat menumbuhkan perasaan dan pemikiran saling menolong. 


\subsection{PENGERTIAN AGEN}

Mengenai Agen Asuransi ini, pada Bab 1 Ketentuan Umum Pasal 1 ayat 28 dalam Undang-undang Nomor 40 Tahun 2014 tentang perasuransian disebutkan bahwasanya Agen Asuransi adalah orang yang bekerja sendiri atau bekerja pada badan usaha, yang bertindak untuk dan atas narna Perusahaan Asuransi atau Perusahaan Asuransi Syariah dan memenuhi persyaratan untuk mewakili Perusahaan Asuransi atau Perusahaan Asuransi Syariah memasarkan produk asuransi atau produk asuransi syariah.

\subsection{TATA PELAKSANAAN KERJA AGEN}

Bagi perusahaan asuransi yang menggunakan sistem keagenan dalam memilih jalur distribusinya, maka keberadaan seorang agen adalah sangat penting dan harus diperhatikan dengan baik dan benar. Oleh karena itu, perusahaan asuransi yang bersangkutan diharuskan memposisikan seorang agen sebagai aset yang sangat berharga. Sehingga sebelum perusahaan melepaskan para agen untuk bertugas dan menjalankan kewajibannya sebagai seorang agen, terlebih dahulu perusahaan memberikan pendidikan dan pelatihan bagi setiap agen. Adapun pendidikan dan pelatihan yang dimaksud mencakup beberapa hal diantaranya pengetahuan tentang profile perusahaan, pengetahuan produk, teori pemasaran dan pemantapan aqidah juga akhlaq (Amrin, 2007, hal. 97).

Setelah mendapatkan pendidikan, setiap agen di beri pelatihan terkait bagaimana tahapan-tahapan melakukan penjualan dengan cara berinteraksi langsung dengan calon nasabah. Adapun tahapan-tahapan tersebut diantaranya sebagai berikut (Amrin, 2007, hal. 97-101):

1. Prospekting, mencari calon peserta atau nasabah.

2. Pendekatan, merupakan proses yang dilakukan oleh setiap agen untuk lebih dekat terhadap prospek calon nasabah yang di tuju.

3. Pencarian fakta, setelah seorang agen mulai menjalin hubungan dengan calon nasabah yang dituju, maka selanjutnya seorang agen diharuskan untuk lebih tahu secara mendalam terkait realita yang terjadi pada calon nasabah.

4. Presentasi produk, merupakan pemberian penjelasan mengenai produk asuransi yang ditawarkan.

5. Penutupan, pada tahap ini nasabah sudah menyatakan untuk membeli produk yang ditawarkan dengan ditandai pengisian formulir surat permintaan. Tahap ini merupakan awal dari pelayanan resmi suatu penjualan kepada pelanggan.

6. Layanan purna jual, setelah pengisian surat permintaan maka setiap agen bertugas memberikan layanan purna jual, seorang agen harus mampu secara bijaksana menjadi penasihat dan konsultan keuangan keluarga nasabah. 
Jurnal Ekonomi dan Perbankan Syariah

Vol. 5. No.1, April 2017: 19-37, ISSN (cet): 2355-1755 | ISSN (online): 2579-6437

\section{| 27}

2.6 KODE ETIK AGEN

Merupakan satu pedoman yang mengatur sekaligus membatasi pola agen dalam menjalankan tugas dan juga kewajibannya. Seorang agen asuransi yang berkualitas menurut pemegang polis adalah agen yang dapat berperan sebagai penasihat yang baik, memiliki wawasan, pengetahuan akan produk dan perusahaannya dengan baik, memiliki akhlaq dan sopan santun, peduli dan mudah bergaul (Amrin, 2007, hal. 112-117). Berikut kode etik bagi seorang agen :

\section{Sikap seorang Agen}

Dalam perspektif ekonomi islam terdapat beberapa sikap yang menjadi modal dasar seorang agen sebagai pemasar produk syariah. Beberapa modal dasar sikap tersebut adalah sebagai berikut (Amrin, 2007, hal. 112-114):

1. Bertanggung Jawab, seorang agen asuransi syariah bertanggung jawab bukan hanya semata-mata kepada klien atau pemegang polis namun lebih bertanggung jawab lagi kepada Allah swt.

2. Mandiri, sifat tidak bergantung pada orang lain. Karena pada hakikatnya seseorang tidak selamanya bisa bantu membantu kita terkecuali dari kita yang harus berusaha sedapat mungkin untuk melakukannya.

3. Kreatif, seorang penjual atau pemasar, dalam hal ini seorang agen akan sangat terbantu dalam perjalanannya memasarkan suatu produk dengan memiliki sebuah kreatifitas atau sifat kreatif.

4. Selalu optimis dan tidak mudah putus asa, suatu sikap yang melekat pada jiwa seorang agen, yaitu niat yang kuat disertai dengan keyakinan akan tercapainya suatu tujuan dengan syarat adanya komitmen dan kesungguhan dalam upaya pencapaian tujuan tersebut.

5. Jujur dan dapat dipercaya, seorang agen asuransi syariah harus menyampaikan, menginformasikan dan mempresentasikan keadaan produk yang di tawarkan dengan sebenar-benarnya dan atau sesuai keadaannya bukan mengada-ada atau membuat opini palsu.

6. Sabar dan tidak panik ketika mengalami kegagalan.

\section{Menghindari Empat Penyakit Hati}

Selain beberapa modal dasar sikap yang harus dimiliki oleh seorang agen, berikut juga beberapa hal yang harus dihindari oleh seorang agen:

1. Berburuk Sangka, seorang agen asuransi syariah tidak diperkenankan memiliki prasangka buruk kepada calon nasabah prospeknya atas segala bentuk penolakan dan juga terhadap kompetitor perusahaan asuransi yang lainnya. Seorang agen asuransi syariah yang sukses adalah mereka yang memiliki prasangka baik terhadap calon nasabah dan juga kompetitornya. Prasangka yang 
baik akan menimbulkan kemauan yang kuat untuk terus berusaha dan terhindar jauh dari kemalasan.

2. Menjelek-jelekkan atau menggunjing, tidak diperkenankan bagi seorang agen untuk melakukan propaganda terhadap calon nasabahnya karena dapat merusak citra perusahaan asuransi yang bersangkutan dan dapat melanggar kode etik seorang agen.

3. Memata-matai, seorang agen tidak diperkenankan untuk mencaricari kesalahan dan kelemahan suatu produk dari perusahaan asuransi lain untuk kemudian disebarkan kepada para prospek calon nasabahnya dengan motif memenangkan persaingan.

4. Mengadu Domba, hanya menawarkan satu macam produk asuransi saja dan hanya satu perusahaan asuransi saja. Seorang agen tidak diperkenankan menjual dua produk asuransi dari dua perusahaan yang berbeda sekaligus karena hal tersebut akan menyebabkan timbulnya perselisihan yang berakibat fatal bagi pihak-pihak yang terkait.

\section{HASIL DAN ANALISIS}

\subsection{PERAN AGEN ASURANSI SYARIAH}

Sejatinya suatu bisnis atau usaha dalam menjalankan kegiatan bisnis atau usahanya memiliki satu tujuan yang hendak dicapai, salah satu diantaranya mewujudkan harapan dan cita-cita untuk maju dan berkembang. Demikian halnya pada kegiatan bisnis asuransi. Kemampuan industri asuransi dalam menghadirkan pelayanan yang terbaik, merupakan salah satu faktor yang dapat mempengaruhi dalam upaya untuk menangkap peluang dan memanfaatkan pertumbuhan ekonomi, menggapai harapan dan cita-cita perkembangan dan kemajuan industri perasuransian di Indonesia (Rahim, 2013, hal. 19).

Pemasaran merupakan satu diantara kegiatan bisnis yang utama, berdampak langsung pada perusahaan yang bersangkutan, menjadi sumber pendapatan dan lain sebagainya. Oleh karena itu, adalah satu kesalahan besar bagi para pelaku bisnis yang tidak memperhatikan aspek pemasaran. Sumber daya insani yang terbatas dalam arti secara komprehensif menguasai syariah dan teknis operasional atau menguasai dalam bidang syariah saja dan sebaliknya hanya menguasai bidang teknis operasional saja merupakan salah satu faktor yang menjadi kendala dalam meningkatkan pemasaran produk asuransi syariah (Sumanto, 2009). Artinya, seorang agen pemasar asuransi syariah dituntut untuk menguasai dua hal sekaligus, yaitu aspek syariah dalam produk asuransi dan teknis operasional yang baik dan benar dalam menjalankan polis asuransi, dari awal menjadi polis sampai pada masa akhir polis asuransi. 
Jurnal Ekonomi dan Perbankan Syariah

Vol. 5. No.1, April 2017: 19-37, ISSN (cet): 2355-1755 | ISSN (online): 2579-6437

Perusahaan asuransi dalam upaya mendorong meningkatkan kinerja agen asuransi dalam pelaksanaan tugasnya adalah dengan memasang pencapaian sebuah target. Target yang realistis perlu disampaikan beserta kinerja keuangan perusahaan asuransi setiap tahunnya guna memberikan gambaran tujuan yang hendak dicapai. Selanjutnya, jadwal pelatihan yang terstruktur dengan baik, dalam mengembangkan fungsi agen sebagai penasihat keuangan dan konsultan juga diperlukan untuk memenuhi permintaan pasar yang bersifat fleksibel sesuai dengan perkembangan zaman (Haron: 2011, hal. 85).

Industri asuransi asuransi syariah dalam melakukan aktivitas pemasaran produk-produk asuransi syariah menggunakan jasa agen pemasar asuransi syariah. Dalam memasarkan produk-produk asuransi syariah, seorang agen asuransi syariah bukan hanya sebatas pada pemasaran namun juga kepada pelayanan kepada calon peserta asuransi syariah. Oleh karen itu, peningkatan peran seorang agen asuransi syariah harus dipahami secara baik dan benar oleh agen asuransi syariah. Adapun peran agen asuransi syariah dalam menjalankan tugas dan kewajibannya, antara lain sebagai berikut:

\section{Sebagai akses jembatan informasi masyarakat tentang asuransi syariah}

Kunci dari pertumbuhan asuransi di Indonesia adalah masyarakat yang belum 'tersentuh' asuransi dan juga pertumbuhan kelas menengah yang merupakan konsumen-konsumen produktif bagi produk-produk asuransi (Setiawan, 2013, hal. 104). Sehingga untuk mengatasi persoalan tersebut kehadiran seorang agen pemasar asuransi menjadi sangat penting. Agen pemasar asuransi sebagai akses jembatan informasi kepada masyarakat tentang keberadaan produk-produk asuransi tersebut. Selain itu, seorang agen juga berperan dalam menanamkan keyakinan dan sikap percaya diri pada masyarakat dalam memilih sebuah produk asuransi.

Pada Pasal 27 ayat 4 Bab V Penyelenggaraan Usaha Peraturan Pemerintah Republik Indonesia Nomor 73 Tahun 1992 tentang Penyelenggaraan Usaha Perasuransian disebutkan bahwa Agen asuransi dalam menjalankan kegiatannya harus memberikan keterangan yang benar dan jelas kepada calon tertanggung tentang program asuransi yang dipasarkan dan ketentuan isi polis, termasuk mengenai hak dan kewajiban calon tertanggung.

Selanjutnya, pada Pasal 31 ayat 2 Bab V Penyelenggaraan Usaha Undang-undang Republik Indonesia Nomor 40 Tahun 2014 tentang Perasuransian juga disebutkan bahwa Agen Asuransi, Pialang Asuransi, Pialang Reasuransi, dan Perusahaan Perasuransian wajib memberikan informasi yang benar, tidak palsu dan/atau tidak menyesatkan kepada pemegang polis, tertanggung, atau peserta mengenai risiko, manfaat dan kewajiban dan pembebanan biaya terkait dengan produk asuransi atau asuransi syariah yang ditawarkan.

Peran agen asuransi sebagai akses jembatan informasi masyarakat tentang asuransi dengan regulasi yang dibuat oleh pemerintah melalui Otoritas Jasa Keuangan (OJK) diharapkan mampu mengoptimalkan peran 
seorang agen. Pada tanggal 21 Oktober 2015 dalam siaran pers yang diselenggarakan oleh Otoritas Jasa Keuangan (OJK), pihaknya tengah mempersiapkan 10 juta agen asuransi dan 1.000 sahabat keuangan maritim. Hal tersebut dimaksudkan untuk meningkatkan akses masyarakat kepada layanan asuransi, asuransi mikro dan syariah serta memperluas jangkauan layanan keuangan pelaku industri dan kelautan (OJK, 2015).

Dengan demikian, seorang agen asuransi syariah sebagai akses jembatan informasi kepada masyarakat tentang asuransi syariah adalah mereka yang telah disiapkan oleh perusahaan asuransi syariah yang siap setiap saat untuk memberikan informasi kepada masyarakat tentang asuransi syariah. Bahkan masuk ke dalam kategori pendampingan untuk masyarakat yang butuh akses informasi tentang asuransi syariah. Sehingga pada akhirnya masyarakat bergabung dengan menjadi peserta polis asuransi syariah.

\section{Sebagai penjaga Citra Perusahaan asuransi syariah di mata masyarakat}

Agen pemasar asuransi adalah ujung tombak yang berfungsi sebagai penjaga citra perusahaan serta industri asuransi di mata masyarakat. Agen pemasar asuransi syariah tidak boleh keliru mempromosikan produk, menginformasikan produk, hingga menjual produk. Karena itu, profesionalitas agen pemasar asuransi syariah sekaligus keberimbangan pengetahuannya antara pengetahuan syariah dan pengetahuan ekonomi menjadi jawaban atas kebutuhan pasar asuransi di Indonesia (Sumanto, 2009).

Melakukan promosi, memberikan informasi dan sampai kepada menjual produk asuransi adalah tahapan tugas sebagai seorang agen asuransi. Ketiga kegiatan tersebut dilakukan secara berkesinambungan dengan tanpa memisahkan satu dengan yang lainnya. Dan perlu dihindari kesalahankesalahan yang berakibat fatal pada tiga kegiatan tersebut. Dampaknya bukan hanya kepada tingkat penjualan yang relatif rendah namun lebih kepada citra dari perusahaan asuransi sekaligus industri asuransi di mata masyarakat. Keterampilan seorang agen asuransi dalam memasarkan sebuah produk asuransi akan sangat membantu dalam aktivitas sebagai agen pemasar asuransi.

Dalam hal ini, profesionalisme yang tinggi harus ada pada setiap agen asuransi syariah yang memasarkan produk-produk asuransi syariah kepada calon peserta polis atau kepada masyarakat. Sehingga masyarakat dapat menilai baik kepada perusahaan asuransi syariah melalui kinerja agen asuransi syariah dalam memasarkan produk-produk asuransi syariah. Bahkan, dalam jangka waktu tertentu secara bertahap masyarakat akan menilai baik juga terhadap perindustrian asuransi syariah.

\section{Sebagai tenaga pemasar produk asuransi syariah}

Strategi dalam memasarkan produk asuransi beragam, mulai dari yang dilakukan secara berkelompok sampai kepada yang dilakukan oleh individu. Dalam pemasaran produk asuransi, strategi pemasaran dengan aspek promosi lebih mendapat prioritas dibandingkan dengan aspek pemasaran yang lainnya 
Jurnal Ekonomi dan Perbankan Syariah

Vol. 5. No.1, April 2017: 19-37, ISSN (cet): 2355-1755 | ISSN (online): 2579-6437

\section{| 31}

(Medyawati, 2013, hal. 57). Aspek promosi adalah strategi pemasaran yang banyak digunakan atau bahkan menjadi strategi unggulan dalam memasarkan produk asuransi.

Jalur keagenan masih menjadi saluran pemasaran yang utama dalam memasarkan produk asuransi jiwa. Dari jumlah total pencapaian premi yang ada, 44,5\% merupakan kontribusi dari jalur keagenan, 36,7\% adalah kontribusi dari jalur bancassurance dan 18,8\% merupakan kontribusi dari jalur pemasar yang lainnya. Yang perlu dicatat tenaga pemasar dalam asuransi jiwa mengalami pertumbuhan sebesar 20,7\%, menjadi 452.836 orang (AAJI, 2015). Hal tersebut menggambarkan minat masyarakat yang tinggi akan profesi seorang agen sekaligus menjadikan agen sebagai jalur pemasar yang efektif dalam memasarkan produk asuransi kepada calon peserta atau masyarakat.

Jasa sales yang terdiri dari people dan promosi dalam memasarkan produk asuransi dinilai lebih efektif karena bertemu langsung dengan calon peserta sehingga memunculkan sikap percaya lebih tinggi dari konsumen untuk bergabung atau menjadi peserta asuransi (Maharani, 2015, hal. 8). Produk asuransi yang dengan sifatnya adalah jasa menjadikan agen pemasar asuransi untuk lebih bisa jauh lebih dekat dalam melakukan komunikasi dengan calon peserta. Dengan demikian diharapkan calon peserta akan lebih mudah menerima dan mengerti atas informasi yang disampaikan oleh agen pemasar asuransi.

4. Memberikan solusi serta pelayanan kepada calon peserta dalam memilih produk asuransi syariah

Dibantu dengan tenaga agen pemasar asuransi yang diharapkan memiliki keahlian atau merupakan agen pemasar yang ahli, perusahaan asuransi akan lebih percaya diri dalam menjalankan kegiatan usahanya. Mengenai keahlian agen pemasar, Liu dan Leach (2001 p.149) menyatakan bahwa keahlian tenaga penjual (agen) merupakan keyakinan akan adanya pengetahuan khusus yang dimiliki tenaga penjual (agen) yang dapat mendukung hubungan bisnis. Hal tersebut diperlihatkan oleh bagaimana seorang tenaga penjual (agen) dalam memberikan solusi dan pelayanan kepada calon peserta (Rachmansyah, 2010, hal. 143). Bukan hanya saja menjual produk asuransi, seorang agen pemasar diharapkan dapat memberikan solusi kepada calon peserta yang terbaik atas apa yang menjadi permasalahan calon peserta, misalnya kesulitan dalam menentukan produk asuransi yang sesuai dengan kebutuhannya.

\section{Memberikan pemahaman yang benar tentang asuransi syariah}

Untuk menjual produk-produk asuransi, seorang agen hendaknya memahami suatu produk yang akan ditawarkan ke calon peserta. Setiap agen memiliki tingkat kemampuan yang berbeda-beda dalam memahami suatu produk asuransi dikarenakan sifat dari setiap produk asuransi yang juga berbeda satu dengan yang lainnya (Amrin, 2007, hal. 71). Pemahaman yang baik tentang 
suatu produk asuransi akan sangat membantu seorang agen asuransi dalam melakukan kegiatan memasarkan produk-produk asuransi.

Hal yang seharusnya menjadi fokus utama seorang agen pemasar asuransi adalah pemahaman tentang asuransi sekaligus upaya dalam memahamkan orang lain atau masyarakat calon peserta asuransi. Dari sekian banyaknya faktor, tingkat pemahaman masyarakat menjadi salah satu faktor yang menyebabkan rendahnya penggunaan asuransi oleh masyarakat (OJK, 2014). Masyarakat belum memahami apa itu asuransi, prosedur dan mekanisme serta hal-hal lainnya yang berkaitan dengan asuransi itu sendiri. Oleh karen itu, asuransi masih terdengar asing di masyarakat yang pada akhirnya menyebabkan rendahnya penggunaan asuransi oleh masyarakat.

Kerja sama yang baik antara agen asuransi sebagai pemasar, pemberi informasi sekaligus pihak yang menawarkan produk asuransi dengan masyarakat, calon peserta sebagai pihak yang akan membeli (polis asuransi), penerima informasi dari seorang agen asuransi. Sehingga tidak ada pihak yang dirugikan oleh pihak yang lainnya. Oleh karena itu, sebaiknya masyarakat dalam memilih suatu produk asuransi melihat atribut dan juga faktor apa saja yang dapat memberikan dampak baik di masa depan, memahami atas segala resiko yang akan dihadapi, mengetahui lebih lanjut tentang produksi asuransi di pasaran, mencari informasi tentang asuransi sehingga memperoleh kenyamanan setelah menjadi polis nanti (Khair, 2014, hal. 99). Dengan terwujudnya suatu kerja sama tersebut dengan baik maka akan membantu kegiatan pemasaran asuransi menjadi lebih mudah untuk ke depannya.

Selanjutnya, seorang agen pemasar asuransi dalam menjalankan kegiatan dan tugasnya memasarkan dan menawarkan sekaligus menjual produk asuransi dituntut untuk memiliki kebesaran jiwa. Sehingga dalam menjalankan tugas dan kewajibannya, seorang agen akan menjaga sikap dan mampu mengendalikan diri serta tidak ikut terbawa kondisi dan situasi. Prosedur pembayaran premi asuransi misalnya, karena salah satu faktor yang menimbulkan anggapan masyarakat bahwa asuransi adalah bukan sebuah kebutuhan baginya, masyarakat masih menganggap bahwa mereka harus membayar premi setiap bulannya, tapi mereka tidak mendapatkan apa-apa dalam jangka waktu pendek. Bahkan masyarakat takut sejumlah uang premi yang dibayarkan setiap bulannya itu tidak akan kembali (Subekti, 2001, hal. 1). Sehingga seorang agen akan dituntut untuk meyakinkan masyarakat dan membenarkan anggapan masyarakat tentang hal tersebut.

Dengan demikian dapat disimpulkan bahwa yang pertama kali dilakukan seorang agen dalam menjalankan tugasnya adalah memberikan informasi secara detail terkait suatu produk asuransi yang dipasarkannya dengan benar. Kemudian memastikan bahwa informasi yang disampaikannya adalah dipahami oleh calon peserta agar tidak terjadi perselisihan dalam perjalanan masa polis ke depannya. Pemahaman pada calon asuransi menjadi satu langkah keberhasilan seorang agen dalam memasarkan produk asuransi. 
Jurnal Ekonomi dan Perbankan Syariah

Vol. 5. No.1, April 2017: 19-37, ISSN (cet): 2355-1755 | ISSN (online): 2579-6437

| 33

3.2 PENINGKATAN PEMAHAMAN MASYARAKAT OLEH AGEN ASURANSI SYARIAH

Dengan melihat kondisi hubungan masyarakat dengan asuransi syariah yang dijelaskan dalam penelitian sebelumnya, maka ada beberapa upaya yang harus dilakukan seorang Agen Asuransi Syariah diantaranya :

1. Meningkatkan Kesadaran masyarakat akan kebutuhan asuransi yang masih rendah.

Sebagaimana dijelaskan dalam penelitian yang dilakukan oleh Gunistiyo dan Subekti (2001) tentang Tingkat Kesadaran Masyarakat Tegal dalam berasuransi, maka seharusnya seorang agen asuransi syariah mengambil bentuk peran semacam pendampingan yang sebelumnya dilakukan workshop, misalnya dengan tema manfaat dan keuntungan berasuransi. Dengan demikian, setelah mengikuti workshop diharapkan masyarakat sedikit banyaknya mengetahui manfaat dan keuntungan berasuransi. Kemudian ditambah dengan dilakukannya pendampingan, diharapkan juga masyarakat akan lebih antusias untuk mengetahui seberapa besar dan manfaat berasuransi. Pada akhirnya masyarakat akan tahu dan sadar akan keharusannya berasuransi.

2. Membuat Strategi Komunikasi Berdasarkan Tingkat Pendidikan dan Pendapatan yang Sangat mempengaruhi kesadaran Berasuransi.

Dalam penelitian Gunistiyo dan Subekti (2001) juga disebutkan, dalam hal ini seorang agen asuransi syariah diharuskan agar dapat menempatkan diri dan calon nasabah dalam memasarkan produk-produk asuransi syariah. Seorang agen asuransi syariah diharuskan dapat membedakan strategi dalam memasarkan produk asuransi syariah yaitu dengan melihat latar belakang pendidikan calon peserta. Begitu halnya dengan tingkat pendapatan, seorang agen asuransi syariah diharuskan dapat menempatkan calon peserta dengan melihat tingkat pendapatan calon peserta.

3. Mencari Solusi atas Keraguan Masyarakat untuk menyampaikan tentang Asuransi Syariah ke yang lainnya.

Sebagaimana yang disampaikan oleh Muhammad Johari (2010) dalam penelitiannya, Respon Masyarakat Muslim kota Mataram terhadap asuransi syariah mencatat bahwa masyarakat masih ragu untuk menyampaikan informasi tentang asuransi syariah kepada orang lain di sekitarnya. Dalam hal ini seorang agen diharuskan untuk memberikan nilai percaya diri kepada calon peserta bahwa informasi yang didapatkannya itu merupakan hal yang sayang jika hanya sampai kepadanya saja dan tidak disampaikan kepada orang lain. Calon peserta diberikan kewenangan dalam mengolah informasi yang didapatkannya untuk kemudian dapat dicerna dengan baik serta selanjutnya dapat menyampaikannya kepada orang lain disekitarnya. 


\subsection{REVITALISASI PERAN AGEN ASURANSI ASURANSI SYARIAH}

Pada umumnya peran keduanya, agen asuransi dan asuransi syariah adalah sama yaitu memasarkan produk-produk asuransi kepada calon peserta asuransi pada khususnya dan juga kepada masyarakat pada umumnya. Akan tetapi ada beberapa revitalisasi peran agen asuransi syariah, diantaranya sebagai berikut :

Tabel 2. Revitalisasi Peran Agen Asuransi Syariah

\begin{tabular}{|c|c|c|c|}
\hline No & Perihal & Agen asuransi & Agen Asuransi Syariah \\
\hline 1 & $\begin{array}{l}\text { Sebagai akses } \\
\text { jembatan informasi } \\
\text { kepada masyarakat } \\
\text { tentang asuransi }\end{array}$ & $\begin{array}{l}\text { Orientasi pelayanan } \\
\text { yang dilakukan } \\
\text { sebagai akses } \\
\text { jembatan informasi } \\
\text { kepada masyarakat } \\
\text { tentang asuransi } \\
\text { adalah terbatas pada } \\
\text { transfer informasi. }\end{array}$ & $\begin{array}{l}\text { Orientasi pelayanan } \\
\text { yang dilakukan sebagai } \\
\text { akses jembatan } \\
\text { informasi kepada } \\
\text { masyarakat tidak hanya } \\
\text { terbatas pada transfer } \\
\text { informasi namun lebih } \\
\text { kepada pendampingan } \\
\text { secara emosional dan } \\
\text { spiritual kepada } \\
\text { masyarakat. }\end{array}$ \\
\hline 2 & $\begin{array}{l}\text { Sebagai penjaga citra } \\
\text { perusahaan asuransi } \\
\text { di mata masyarakat }\end{array}$ & $\begin{array}{l}\text { Dalam menjalankan } \\
\text { kegiatan memasarkan } \\
\text { produk asuransi, } \\
\text { penjagaan terhadap } \\
\text { citra perusahaan } \\
\text { menjadi hal yang } \\
\text { penting setelah } \\
\text { berhasil menjual } \\
\text { produk asuransi. } \\
\text { Sehingga } \\
\text { profesionalitas } \\
\text { kurang diperhatikan } \\
\text { dalam memasarkan } \\
\text { produk asuransi } \\
\text { kepada masyarakat } \\
\text { atau calon peserta } \\
\text { polis asuransi. }\end{array}$ & $\begin{array}{l}\text { Dalam menjalankan } \\
\text { kegiatan memasarkan } \\
\text { produk asuransi, } \\
\text { penjagaan terhadap citra } \\
\text { perusahaan menjadi hal } \\
\text { yang utama, dengan } \\
\text { mengedepankan } \\
\text { profesionalitas dalam } \\
\text { memasarkan produk } \\
\text { asuransi untuk } \\
\text { mencapai keberhasilan } \\
\text { menjual produk asuransi } \\
\text { kepada masyarakat atau } \\
\text { calon peserta polis } \\
\text { asuransi. }\end{array}$ \\
\hline 3 & $\begin{array}{l}\text { Sebagai tenaga } \\
\text { pemasar/penjual } \\
\text { produk asuransi }\end{array}$ & $\begin{array}{l}\text { Metode yang } \\
\text { digunakan dalam } \\
\text { memasarkan produk } \\
\text { asuransi merupakan } \\
\text { metode transaksi jual } \\
\text { beli seperti biasanya } \\
\text { yang berbasis pada } \\
\text { 'asal' suka sama } \\
\text { suka. }\end{array}$ & $\begin{array}{l}\text { Metode yang digunakan } \\
\text { dalam memasarkan } \\
\text { produk asurani bukan } \\
\text { hanya saja seperti } \\
\text { transaksi jual beli } \\
\text { sebagaimana biasanya } \\
\text { namun dengan adanya } \\
\text { proses pendekatan atau } \\
\text { berasaskan } \\
\text { kekeluargaan. }\end{array}$ \\
\hline
\end{tabular}




\begin{tabular}{|c|c|c|c|}
\hline 4 & $\begin{array}{l}\text { Memberikan solusi } \\
\text { serta pelayanan } \\
\text { kepada calon peserta } \\
\text { dalam memilih } \\
\text { produk asuransi }\end{array}$ & $\begin{array}{l}\text { Pelayanan yang } \\
\text { dilakukan sebatas } \\
\text { membantu calon } \\
\text { peserta asuransi untuk } \\
\text { mudah memilih } \\
\text { produk asuransi mana } \\
\text { yang sesuai dengan } \\
\text { kebutuhannya. }\end{array}$ & $\begin{array}{l}\text { Pelayanan yang } \\
\text { dilakukan bukan hanya } \\
\text { sebatas membantu calon } \\
\text { peserta untuk mudah } \\
\text { memilih produk } \\
\text { asuransi yang sesuai } \\
\text { dengan kebutuhan calon } \\
\text { peserta namun sekaligus } \\
\text { memberikan solusi atas } \\
\text { permasalahan dalam } \\
\text { memilih produk } \\
\text { asuransi. }\end{array}$ \\
\hline 5 & $\begin{array}{l}\text { Memberikan } \\
\text { pemahaman yang } \\
\text { benar tentang } \\
\text { asuransi }\end{array}$ & $\begin{array}{l}\text { Pemahaman yang } \\
\text { diberikan kepada } \\
\text { masyarakat masih } \\
\text { terbatas pada dasar- } \\
\text { dasar praktek } \\
\text { berasuransi. }\end{array}$ & $\begin{array}{l}\text { Pemahaman yang } \\
\text { diberikan kepada } \\
\text { masyarakat atau calon } \\
\text { peserta bukan hanya } \\
\text { terkait dasar-dasar } \\
\text { praktek berasuransi } \\
\text { namun pemberian } \\
\text { pemahaman secara } \\
\text { detail terkait hal-hal } \\
\text { yang dimungkinkan bisa } \\
\text { saja terjadi saat } \\
\text { perjalanan masa polis } \\
\text { dan bagaimana cara } \\
\text { mengatasinya. }\end{array}$ \\
\hline
\end{tabular}

Sumber : Data yang diolah

Dari sekian beberapa perbedaan yang dijelaskan dalam tabel diatas yang utama adalah modal pemahaman dari seorang agen. Seorang Agen Asuransi Syariah, dalam memahami produk asuransi syariah yang dipasarkannya bukan hanya sekedar memahami saja. Pemahaman yang dilandasi dengan pelaksanaan pada seorang agen asuransi syariah itu sendiri adalah penting.

\section{SIMPULAN}

Dari pembahasan dalam penulisan ini, tentang peran agen asuransi syariah dalam meningkatkan pemahaman masyarakat tentang asuransi syariah, dapat disimpulkan bahwa peran agen asuransi syariah diantaranya sebagai akses jembatan informasi kepada masyarakat tentang asuransi syariah, yaitu pusat informasi bagi masyarakat mengenai asuransi syariah dan produk-produk asuransi syariah. Oleh karena seorang agen asuransi syariah merupakan orang 
kepercayaan dari perusahaan, seorang agen asuransi syariah berperan sebagai penjaga citra perusahaan asuransi syariah di mata masyarakat.

Seorang agen asuransi syariah juga berperan sebagai tenaga pemasar produk asuransi Syariah yang menawarkan sampai bisa menjual produkproduk asuransi syariah kepada calon peserta dan juga masyarakat. Bukan hanya sekedar menjual produk-produk asuransi syariah saja, seorang agen asuransi syariah juga berperan untuk memberikan solusi serta pelayanan terhadap calon peserta dalam memilih produk asuransi Syariah. Solusi yang sesuai dengan kebutuhan calon peserta serta pelayanan yang terbaik juga diberikan kepada calon peserta.

Selanjutnya, seorang agen asuransi syariah berperan dalam memberikan pemahaman yang benar tentang asuransi syariah kepada calon peserta atau masyarakat. Pemahaman yang dilandasi dengan kebenaran praktik yang juga dilakukan seorang agen asuransi syariah sendiri. Dalam memberikan pemahaman kepada calon peserta atau masyarakat, seorang agen asuransi syariah tidak diperkenankan untuk merekayasa pemahaman karena hal tersebut melanggar kode etik seorang agen asuransi syariah.

\section{DAFTAR PUSTAKA}

AAJI. (2015). Industri asuransi Jiwa Berhasil Bukukan Pertumbuhan Positif di Tengah Melambatnya Pertumbuhan Ekonomi Nasional. Siaran Pers.http://www.aaji.or.id/file/ uploads/content/file/AAJI\%20Q2\%202015_Siaran\%20Pers\%20Rev\% 204\%20_clean_ws.pdf.

AASI. (2014). Data Bisnis Asuransi dan Reasuransi Syariah. Dipetik January 31, 2016, dari http://www.aasi.or.id/aset/img/upload/data bisnis asuransi dan reasuransi syariah/Data Bisnis Asuransi dan Reasuransi Syariah AASI Q4 2014. Pdf

Al-Bugha, M. D. (2009). Buku Pintar Transaksi Syariah. Damaskus: Darul Musthafa.

Ali, Z. (2008). Hukum Asuransi Syariah. Jakarta: Sinar Grafika.

Amrin, A. (2007). Strategi Pemasaran Asuransi Syariah. Jakarta: PT Grasindo.

Sumanto, Agus Edi, E. P. (2009). Solusi Berasuransi: Lebih Indah dengan Syariah. Bandung: PT Salamadani Pustaka Semesta.

Haron, H., Ismail, I., \& Razak, S. H. A. (2011). Factors influencing unethical behavior of insurance agents. International Journal of Business and Social Science, 2(1).

Iqbal, M. (2005). Asuransi Umum Syariah dalam Praktik. Jakarta: Gema Insani Press. 
Jurnal Ekonomi dan Perbankan Syariah

Vol. 5. No.1, April 2017: 19-37, ISSN (cet): 2355-1755 | ISSN (online): 2579-6437

| 37

Johari, M. (2010). Respon Masyarakat Kota Mataram terhadap Asuransi Syariah. Tesis, Yogyakarta: UIN Sunan Kalijaga.

Pasaribu, H. K. (2014). Atribut Kinerja Pelayanan Dalam Mempengaruhi Masyarakat Kota Medan Memilih Perusahaan Asuransi. Jurnal Ilmiah Manajemen \& Bisnis, 14(01).

Maharani, N. P. V., Zukhri, A., \& Suwena, K. R. (2015). Analisis FaktorFaktor Yang Mempengaruhi Masyarakat Di Kota Singaraja Memiliki Program Asuransi Unitlink. Jurnal Jurusan Pendidikan Ekonomi, 5(1).

Abdullah, N. I., Salleh, M. C. M., \& Razali, S. S. (2013). Measuring Takaful Agents' Understanding Towards The Objectives and Concepts of Takaful. Journal of Islamic Finance, 2(1), 20-30.

Fayshal, A., \& Medyawati, H. (2013). Analisis Strategi Pemasaran Produk Asuransi Jiwa Pada Bumi Putera Syariah Cabang Depok. Jurnal Asuransi dan Manajemen Risiko, 1(2).

OJK. (2015, October 21). Siaran Pers: OJK Siapkan 10 Juta Agen Asuransi dan 10 Ribu Sahabat Keuangan Maritim. Dipetik November 26, 2015, dari OJK: http://www.ojk.go.id/id/kanal/iknb/berita-dan kegiatan/siaran pers/Pages/OJK-Siapkan-10-Juta-Agen-AsuransiSahabat Keuangan-Maritim.aspx

Djauhari, D., \& Rachmansyah, Y. (2010). STRATEGI MENINGKATKAN KINERJA PENJUALAN ASURANSI JIWA (Studi Di AJB BUMIPUTERA 1912 Kantor Cabang Semarang). PRESTASI, 6(01).

Rahim, H. (2013). Optimisme Pertumbuhan Asuransi Indonesia; Proyeksi Perkembangan Lima Tahun (2014-2018). Jurnal Asuransi dan Manajemen Risiko, 1(2).

Saharuddin, D. (2014). Aplikasi Claim Settlement Pada Asuransi Umum Syariah (Studi Analisis terhadap Syariah Complaince). Jakarta: Rausyan Fikr Press.

Setiawan, S. (2013). Prospek dan Daya Saing Sektor Perauransian Indonesia di Tengah Tantangan Integrasi Jasa Keuangan. Kajian, 104. http://www.kemenkeu.go.id/sites/default/files/2013_kajian_pkrbPro spek_Sektor_Perasuransian_Indonesia_Dalam_AEC_2015.pdf

Subekti, G. d. (2001). Tingkat Kesadaran Masyarakat Tegal dalam Berasuransi.

http://download.portalgaruda.org/article.php?article=116867\&val=533 $\&$ title=TINGKAT\%20KESADARAN20MASYARAKAT\%20TEGA L\%20DALAM\%20BERASURANSI

Sula, M. S. (2004). Asuransi Syariah (life and general): Konsep dan Sistem Operasional. Jakarta: Gema Insani Press. 
38 | Hariyadi \& Triyanto: Peran Agen Asuransi Syariah dalam Meningkatkan... 